\title{
Kierkegaard on the beneficial yoke of suffering
}

\author{
Bojan Zalec
}

DOI: 10.18355/XL.2020.13.03.01

\begin{abstract}
The paper deals with Kierkegaard's account of human suffering which is a variant of theodicy. Its main thesis is that, according to Kierkegaard, God brings suffering only to those that he loves. His position is quite radical and challenging, also because at the same time his main staring point is the belief that God is love. The author explains Kierkegaard's position by referring to his understanding of love, obedience, faith and bliss. His aim is to show its complexity, but at the same time intelligibility when understood in the framework of Christian grammar, and to distinguish it from too simplistic understandings in the sense of God's pedagogy.
\end{abstract}

Key words: Kierkegaard, suffering, God, love, Christianity, obedience

"My yoke is beneficial and my burden is light." (Kierkegaard, 1993: 232)

\section{Introduction}

In this article I deal with Kierkegaard's explanation and conception of human suffering. There are few thinkers so crucial for contemporary European philosophical thought as Kierkegaard. (Khan, 2018: 2) Therefore, his accounts are already as such extremely relevant for contemporary philosophical thought. Similarly, the issue of suffering is crucial to any ethic. This is also true of the present times: think only of all ongoing debates on euthanasia, or of transhumanist ideas about reducing suffering or even eliminating it. (Peters, 2011: 65) Likewise, the question of theodicy is a central issue in the philosophy of religion as it is true at the same time that many prominent thinkers of the $20^{\text {th }}$ century rejected any theodicy as unacceptable in the wake of the horrors we experienced in the twentieth century. (Levinas, 1998: 100, 162) However, this same century, on the other hand, witnessed the horrific expulsion of nihilism and its devastating consequences. Kierkegaard links those two aspects in his understanding of suffering: theodicy, and the question of meaning, which directly concerns nihilism. He recognizes that suffering is a major touchstone of both, our faith in God and question of meaning. He offers a radical response to the challenge of suffering, which is "shocking" to many Christians as well as other believers or "unbelievers". He proceeds from the claim that God is love as a fundamental (Christian) truth. This "truth" is warmly welcomed today by many in our secular age in Taylor's sense (Taylor, 2007); even many of those who do not believe in God agree that only God who is love is - or would be - acceptable. However, Kierkegaard adds the thesis that is simply repulsive to many (modern) people: precisely because God loves us, he "brings us" suffering. At this point, I must immediately remark that he does not have in mind the simple pedagogy of God's punishment and education with diseases, natural disasters, etc. I believe that Kierkegaard's view of suffering is extremely challenging and also relevant to modern times, which want to push suffering away but, of course, cannot escape it. Doesn't the current coronavirus epidemic remind us again that that is not possible? And with that we touch the next Kierkegaard's point, which is far more realistic than elimination of suffering option: we cannot escape suffering, but we can make it easier to bear its burden. In fact, Kierkegaard's Christian claim is even more radical: only those who bear the yoke of their suffering with joy will be redeemed or blessed. 
It can be said that Kierkegaard defends suffering in some way, since he explains that suffering as such is not evil and as such does not originate from evil. As mentioned earlier, Kierkegaard's account is complex and demanding, as it involves and presupposes understanding of the central and most complex notions of his thought: love and faith, and all that is included and assumed by them, especially obedience. My intention is to show the intelligibility of Kierkegaard's position, at least within Christian grammar. Where there is intelligence, there is also a sense and possibility of accepting suffering. Every opportunity that allows one to understand, reflect, and accept suffering is extremely valuable, since we have no other reasonable options: to live with something that cannot be eliminated and not be accepted at the same time is clearly unreasonable and self-destructive, and life without suffering is just an empty illusion. So it remains the path of self-transformation that allows one to accept suffering. How to achieve such transformation, what makes it possible? Contribution to the answer on this question was Kierkegaard's aim, as well as it is the purpose of this article.

\section{There is no love and no obedience without suffering}

Kierkegaard analyses suffering as a grammarian of genuine Christianity (Roberts, 1995: 148-155; Zalec, 2018: 51-52) but also as a lucid psychologist. His central question is "What is to be a Christian?" and from this starting point he investigates what is a true Christian attitude toward suffering. His position is quite radical. He claims that suffering is an inevitable part of Christian life because a man cannot love God without suffering themselves, or being unhappy humanly speaking (Walsh, 2009: 66). If one loves God, one necessary suffers. Man can love God only in suffering. (Kierkegaard 1998: 294) On the other hand, that we love God is God's gift. God knows that one cannot love him without suffering. So he "causes" suffering to those he has "chosen" for good, to those whom he loves. (Walsh, 2009: 73) It is not the devil who is the origin of suffering but rather God himself (Walsh, 2009: 72-73). He "tortures" only those he loves. Suffering is not a sign of being punished by God but rather of being loved by God. God doesn't punish by suffering but rather with ignorance. (Walsh, 2009: 73) The punished are not tortured by God by suffering but by being detached from him. (Kierkegaard, 1955: 34-35)

Christians believe that God is love. This is, for Kierkegaard, "the main 'thesis of Christianity" (Walsh, 2009: 66). According to Kierkegaard that God is love means not only that God loves us but also that God wants that we love him. God's love for us implies his willing that we love him. The reason for that is that love is equality. God loves himself and he wants to "make us" - out of love - similar and "equal" to him. (Walsh, 2009: 66) But human love for God is according to Kierkegaard logically equivalent to faith (Zalec, 2017a: 185-186) so there is no love for God without faith. But - as I will show below - there is no faith without obedience, no obedience without suffering, and thus no faith without suffering. (Tavilla - Kralik - Roubalova, 2019: 220-222; Valco, 2016)

Through suffering we are becoming similar to God, we are becoming like God. God's "torturing" is a sign of his love because through "torturing" he promotes us and makes us "equal" to him. God loves us and wants us to love him. Love is "equality" "because the god wills to be equal of the lowliest of the lowly out of love" (Walsh, 2009: 116). But he does not "make us" equal to him through adoration of "chosen" persons, and thus by glorification of himself, but rather through his descent into likeness of man. (Walsh, 2009: 65-66) Yet this descent implies God's suffering. So from both sides - divine and human - achieving of similarity between God and man, which is needed for true love, implies suffering of both, God and man. In short, there is no love without suffering. (Binetti, Pavlikova, 2019)

I have already mentioned that faith and human love for God are - in this world logically equivalent: there is no love without faith and vice versa. So faith implies 
suffering. But despite all the suffering which faith includes the real purpose of faith is gaining, not losing. By faith, and eo ipso by suffering, one gets everything: they get their love of God which is the end of human life and the necessary and sufficient foundation of good life. St. Augustin's slogan "Love, and do what thou wilt!" perfectly fits also to Kierkegaard's view. According to Kierkegaard, every true love is founded upon the love for God. (Zalec, 2017a: 185-186)

In order to love God one must suffer. This is, according to Kierkegaard, the message of the New Testament. Kierkegaard does not justify his position about suffering on some "neutral", scientific or "rational" ground. He just explains and makes "understandable" the grammar of suffering which is already given in the Bible. The basic reason that a true Christian must suffer is, as we have already explained, that suffering is necessary for having a loving relationship with God which is necessarily reciprocal: one can't love God without being loved by God. The next reason for the necessity of suffering of a true Christian is that Christianity is in a sharp collision with the world which is immersed in sin. Christianity is an offense for the world. This necessary leads to the suffering of a true Christian. A Christian is in opposition to the world and his attitude to it must be "militant", claims Kierkegaard. (Kierkegaard, 1991a: 201-232, 251) "Militant" according to Kierkegaard doesn't mean violent, a use of force etc. Rather it means a non-compromising refusal of accepting (as a Christian) anything what is not Christian and to live a genuine Christian life stubbornly. But this "alas" necessary leads to the conflict with the world. Thus being a true Christian in the world as it is already implies holding a militant attitude toward the world. Really being a Christian and not being in a conflict with world, not being an offense to the world, not contributing to "destruction" of the world as it is, this is according to Kierkegaard impossible. Such a militant stance is in opposition to the position of Christendom according to which "we are all Christians". Kierkegaard claims that if we are all Christians, then true Christianity disappears, then there is no Christianity in the world. (Kierkegaard, 1991b: 127; 1995: 64) Kierkegaard has opposed to the outselling of Christianity in order to form a triumphant Church which triumph is based on the massive Christianity, on the number of its members. Such Church is possible only for the price of abolishing of genuine, "militant" Christian attitude, in short of true Christianity. The essence of genuine Christianity is love for God and one cannot love God without being in conflict with the world. (Kierkegaard, 1991b: 127) Heaven on earth is not possible and "forgetting" this leads just to the destruction of Christianity. The task of a Christian is not a distortion of the Christian doctrine and practice in order to make it possible that all are Christians, but witnessing by their lives and suffering for a genuine Christianity, being a true servant and collaborator of God on this world. All other things are beyond man's control and competence. Such a genuine Christian attitude is an expression of trust in God. Faith is essentially such a trust. (Westphal, 2014: 26-39)

Kierkegaard doesn't think that every suffering is good. Thus for instance he warns against non-useful suffering. (Kierkegaard, 1998: 294; Benjamin \& Cuff Snow, 2012: 35-36) But what is a criterion for distinguishing the right suffering from the wrong one? What is Kierkegaard's normative ethics of suffering? To this question, it is very difficult to give a useful answer based on some textual evidence from Kierkegaard's oeuvre. Maybe this question is a wrong, ill posed question because there is no general answer. A Christian must ask themselves from their personal, concrete, and "subjective" point of view: can I suffer or avoid this particular suffering or not? Is it ethically right or wrong if I avoid or accept particular action or attitude because it brings suffering (to me)? There is no general receipt whether a particular suffering is useful or not and we must decide separately in each particular situation what is the right thing to do. Kierkegaard was a (radical) virtue ethicist (Tietjen, 2013: 117, 130134; Zalec, 2018: 51-52) and not a representative of ethics of principles, like for 
instance Kant or utilitarians. (Kondrla - Durkova, 2018: 46-47) He focuses on the question of the formation of a Christian person, on Christian character and virtues, on their characteristics and specifics, not on formulating of "law(s)" of ethics. (Martin Rojas - Kralik, 2020: 44) According to Kierkegaard, our task is to become Christians, to develop Christian character and cultivate Christian virtues and this will help us to decide and act rightly in concrete particular situations, also regarding suffering. Kierkegaard focuses on the question of the role of suffering in being or becoming Christian. This is his real question. What is to be a Christian, not formulation of lawlike normative ethics about Christianity. Let us take an example of the Holocaust which Sylvia Walsh discusses. (Walsh, 2009: 68-70) The Holocaust caused enormous suffering. Was the Holocaust from the Kierkegaardian standpoint actually something good? My answer is that it is totally harmonious with Kierkegaard position to refuse and condemn the Holocaust. The Holocaust was suffering caused by non-Christian, sinful people to other people. God did not cause it and he "couldn't" prevent it because he gave man free will. But the real Kierkegaardian question is not who caused the Holocaust or whether God is the origin of the Holocaust. The real Kierkegaardian question is: Can we, as Christians, on the basis of the fact that the Holocaust happened refuse or give up the belief that God is love? Kierkegaard's answer is clear "No!" and, moreover, he thinks that this would be a disastrous decision. (Kierkegaard, 1993: 267) He also refuses a simple thesis about God's pedagogy through suffering caused to us by nature (diseases, natural catastrophes etc.) or other people. No, God has nothing to do with this or at least there is no evidence and no reason to claim such things. The way in which God "tortures" a believer, the one whom God loves, is simply by giving them the conception of God, by giving them the desire to love God, by giving them faith and courage for faith. A person with such gifts is already on their way to suffering because as such they cannot avoid suffering any more. As soon as one is a true believer, a true Christian, they necessarily suffer, because they don't avoid suffering any more but rather they take their cross voluntarily. Therefore, a true Christian is already as such "unhappy". But, Kierkegaard adds, "unhappy" only humanly speaking. Because, on the other hand, if one really believes that God is love, that God loves them and that man is as such, essentially a sinner, then they will be able to bear the yoke of suffering with joy and find out that Christian suffering brings the greatest joy. According to Kierkegaard, bliss consists of the remembering of suffering which we overcome with the help of God; the greatest bliss is the remembering of the suffering which we have overcome but for which we were not guilty and we suffered it for a good case. (Kierkegaard, 1983: 104-105)

One of the central messages of Kierkegaard is that if you want to please God then you must necessarily suffer because you please God if you love him. (Kierkegaard, 1990: 55) Man can't love God if they don't suffer because they can't be obedient without their suffering (Kierkegaard, 1993: 263) and love for God is impossible without obedience because without faith one can't really love God (Zalec, 2017a: 185-186) yet there is no faith without obedience:

"Only suffering educates for eternity, because eternity is in faith, but faith is in obedience, but obedience is in suffering. Obedience is not apart from suffering, faith is not apart from obedience, eternity is not apart from faith. In suffering obedience is obedience, in obedience faith is faith, in faith eternity is eternity" (Kierkegaard, 1993: 263).

We must believe that against God we are always in the wrong and that God is always in the right. (Kierkegaard, 1993: 268, 272, 274, 277, 283) If we do not believe this then everything collapses. Then the road is open to everything, to every evil. If the principle of the world is not perfect, if God can be in the wrong or if he is not love, then everything is possible, the road to abys is open and there is no guarantee, no true 
safety. (Kierkegaard, 1993: 277; Walsh, 2009: 69) Further, without obedience there is no faith. Without faith, we fall to nihilism. Nihilism is the absence, lack of faith, and exactly suffering is a condition and expression of faith. On the other hand, if one is not obedient then they necessary take a negative attitude toward Christianity, because if one is not obedient they can't perceive Christianity differently as an offense because there is no faith without obedience and "one must either believe in him [Jesus Christ n. the author] or be offended" (Kierkegaard, 1991a: 33; Tietjen, 2013: 112-113, 115). Therefore, in order to be able to avoid the attitude of offense we must be obedient.

\section{Kierkegaard's joyful »news «: »God is love« as a foundation of joy in suffering}

In the remaining part of this paper, I will deal more closely with Kierkegaard's text "The Gospel of Sufferings" (Kierkegaard, 1993: 213-341). It belongs to his upbuilding discourses. The ideas from this discourse nicely complement and clarify what I have said above.

Human earthly life without suffering is at best only a logical possibility, but it is actually impossible. Human "destiny" on earth is to suffer. So we should be already from this reason very motivated in learning how to bear the yoke of suffering with joy. But for Kierkegaard, the interest in this issue originates in some of his further believes or assumptions. First, the way to salvation leads through narrow gate (of suffering). (Kierkegaard, 1993: 228; Kierkegaard, 1991b: 100, 105, 109, 176; Mt 7:13-14; Lk 13:24) Second, only obedient persons can accomplish salvation. Third, being obedient is impossible without suffering. Fourth, suffering alone is only necessary, but not sufficient for being obedient. Fifth, only suffering with joy leads to salvation. The main aim of this Kierkegaard's discourse is to explain his position that a suffering person can be joyful. We should understand "can" in this sentence in twofold sense: as expressing that man is capable of being joyful despite their suffering, and moreover, that they should be happy that they suffer because this means that they might be redeemed because the possibility of salvation without suffering is only an empty illusion. Therefore, we shouldn't envy those who don't suffer but to the contrary, we should pity them. According to Kierkegaard the ground that makes joy in suffering possible are the beliefs that God is love on one hand, and that every human is essentially a sinner before God on the other.

The first evidence for a Christian for the claim that we should suffer with joy is the example of Jesus Christ. Jesus' suffering and the way how he suffered shows us what the right way is. Kierkegaard stresses the following things by Jesus: first, he suffered with joy, his suffering was easy despite the superhuman suffering he suffered. Second, Jesus was meek. (Kierkegaard, 1993: 246-247) Third, he put himself aside (Father's will, not his, should be fulfilled). Kierkegaard observes that only because of his meekness and putting aside of himself he was able to stand his enormous suffering easily and with joy. Kierkegaard's conclusion from that is that we, the imitators of Christ, should try to accomplish the same virtues, attitude and point of view. We should understand that following Christ is the only way in which more suffering means more blessing. He stresses the importance of faith. We must follow Christ despite that we do not see him. (Kierkegaard, 1993: 227) Next, we ourselves must bear our yoke of suffering. We should not let somebody else to carry it instead of us and we should not count that Jesus Christ will carry it instead of us. Jesus has just prepared a place in Haven for us, but the way of suffering that leads to that place everyone must overcome by themselves. (227-228) Also the next finding about obedience Kierkegaard derives from the analysis of Christ's example. He claims that obedience belongs to humiliated. (Strahovnik, 2018, 308-310) Christ's humiliation was that he was a man. And when already for the purest it is true that he can learn obedience only from his own "humiliation" and suffering then this must be true also for a sinful man. (Kierkegaard, 1993: 263) Kierkegaard further adds that suffering 
educates for eternity, because eternity is in faith, faith is in obedience, and obedience is in suffering. (Ibid.) In ontological terms we may say that "in" in the previous sentence denotes the relation between accidence and its bearer, its substance. Thus for Kierkegaard suffering is a substance of obedience which fits to the fact that obedience without suffering is not possible but not vice versa. Besides, those persons who learn from their own suffering ceaselessly get to know something about themselves, and about their relationship to God. This is another sign that suffering is education for eternity. (Kierkegaard, 1993: 257)

Kierkegaard's next reason for the claim that suffering is necessary for man's bliss is his belief that suffering is a school of obedience and that one's suffering is necessary for their becoming obedient. Lack of obedience has several serious negative consequences. The most important is that faith and thus salvation is given only to the obedient. But already in earthly life, lack of obedience is a serious trouble because without obedience man sinks into despondency and nihilism. One origin of this sinking could be that the less obedient a person is the heavier is their burden. Therefore, according to Kierkegaard, one cannot be free if they do not suffer. Therefore, suffering and obedience are natural conditions of any truly happy man. At this point we again hit upon Kierkegaard's central idea that the fundamental origin of human happiness and misery is their (dis)connectedness to eternity, i.e. God. Kierkegaard observes that in suffering man learns that God rules, and then he asks rhetorically:

"But what is all eternal truth except this: that God rules; and what is obedience except this: to let God rule; and what other connection and harmony are possible between the temporal and the eternal than this that God rules and to let God rule" (Kierkegaard, 1993: 257)

Why is the awareness about man's own guilt important? A short answer is that because it protects our faith that God is love that is the foundation of joy in suffering. (Kierkegaard, 1993: 268-269) The beliefs that God exists, that God is love, and that he loves us are necessary for man's being able to stand suffering and not starting to hate themselves and others. One's suffering as truly innocent, without any guilt, is incompatible with God's being love and his love for the innocent sufferer. At this point, faith is very important because for maintaining our belief that God is love when faced with the suffering of an "innocent" person - we need even more faith. The struggle of faith is the struggle for the believing without understanding, stresses Kierkegaard (Kierkegaard, 1993: 273) Eternal happiness is in faith, not understanding, that God is love. When doubt presses one's faith then the awareness about one's own guilt comes as an external help, as a saviour. (Kierkegaard, 1993: 273.) God fights with his attacker by means of the awareness about guilt. When one attacks God, the awareness about guilt attacks the attacker, and the attacker fights with himself. (Kierkegaard, 1993: 286) True faith understands that it is not possible to understand God through doubt and that a blessing consists in the impossibility of doubt and especially in the impossibility of doubt that God is love. (Kierkegaard, 1993: 274) If it is possible that there is a person who suffers without having any guilt then God cannot be love and the belief that he loves every person is unacceptable. It follows that the dogma about the original sin is necessary for man's joy in suffering and therefore for man's true happiness. The one who claims that this dogma is absurd must create a life in which suffering is not possible. But such a life is clearly impossible. A belief in its possibility is only an illusion moreover, from the Christian and Kierkegaardian point of view, this is a sinful and very harmful illusion. It contradicts the revelation and leads to abandoning of faith and negative attitude towards Christianity. Additional reason for joy brings the finding that the truth that God is love is so firm that nothing can undermine it. If there is any ground for doubt, then the one who doubts must prove that somebody is innocent before God. If one cannot prove it, and it is 
impossible to prove it, then the doubt is shaken and destroyed. (Kierkegaard, 1993: 274-275)

The next importance of awareness about man's own guilt is related to the meaningfulness of our lives. If we are always, i.e. necessarily and essentially, guilty then there is always a task for us and then is always a meaning. A guilt before God implies task, hope and meaning. But if there is no task then we find ourselves in the horror of hopelessness. (Kierkegaard, 1993: 275-281) This is another reason for the thesis that suffering is necessary for overcoming of nihilism because hopelessness and nihilism are closely related. So suffering is necessary for a good life but it must be always accompanied by awareness that we are always guilty before God because otherwise suffering might have bad, undesired effects, for instance negative feelings, which can have bad consequences, for instance violence. Suffering is a dangerous education or cure if the person does not learn to be obedient. It is like a medicine that does not work and the patient has wrong reaction. (Kierkegaard, 1993: 255-266) On the one hand suffering is the greatest danger but on the other hand it brings the greatest gain, i.e. eternity. In any event, all existential tasks of man are founded on their belief that God is love. Everyone who does not believe that God is love is according to Kierkegaard despaired because they do not trust in God. When such man is in troubles, they don't look humbly at God but rather stab him with their glaring, says Kierkegaard. (Kierkegaard, 1993: 277) Even the bandit who was crucified together with Jesus and who went through his very last moments, he still had a task. This task was repentance and regret. He knew that God has not abandoned him but that rather he has abandoned God. For this reason, he repentantly asked Jesus to remember him when coming to his kingdom. (Kierkegaard, 1993: 280) Being abandoned by God, according to Kierkegaard, means to be without a task. Kierkegaard has put in the bandit's head the following consideration (I summarize it with my own words) (Kierkegaard, 1993: 281):

"Every man who suffers is guilty before God and because of this no man has been abandoned by God. Jesus is the only one without any sin but despite this he suffers. Therefore we may say that God has abandoned him and that his suffering is super-human. But contrary to Jesus, God has never abandoned man and man has always a task. This is a comfort for anyone who admits that they suffer as guilty, also for me. Also for me there is a task and therefore God hasn't abandoned me."

God is holy and man is sinful - this is, according to Kierkegaard, the basic relationship between God and man. The relationship between humans is such that one can be guilty or not, they can be in the right or wrong etc. But this cannot be a relationship between man and God because otherwise they would be equal. God would not be God. (Kierkegaard, 1993: 285) Only a Christian "knows" that there is only one who suffered before God and who is totally innocent. (Kierkegaard, 1993: 287) For this reason, according to Christian faith, nobody should dare to compare themselves with Jesus Christ. It follows that everyone suffers before God as guilty. Denial of this is a denial of Christian faith. Now we can clearly understand why Kierkegaard has chosen the title "The Gospel of Sufferings"? Gospel is joyful news. Kierkegaard whit his discourse brings the joyful news that we should and can suffer with joy, moreover, that we can suffer with greatest joy.

\section{Conclusion}

Kierkegaard argues that suffering plays a very important and indispensable positive role in human life. For example, it is necessary for obedience. Only through suffering one can learn obedience. And if man does not learn to be obedient then they sink into 
nihilism. But only suffering as such is not sufficient. We must suffer with joy. Otherwise the "medicine" of suffering can have very damaging effects. So the question about conditions and factors of the joy in suffering is very important. In this regard, the key role is played by the consciousness about person's own guilt which protects them from doubting the truth that God is love (or even its denial). If we believe that God is love and that we are always guilty before God then there is always some task for us and this means that we are not left to hopelessness and that our life has meaning. (Valco, 2017) If it were possible that the one who suffers is totally without guilt then there would be no task. But such state is a state of hopelessness. Kierkegaard's view on joy in suffering is placed in the broader frame of his art of life pervaded by his general belief that the origin of human unhappiness, pathology, negative feelings, depression and finally violence is human non-acceptance of themselves. (Zalec, 2017b: 33-36) This belief was confirmed again also in his text and reflexions discussed in this paper. The aspect of ourselves which is in focus in "The Gospel of Sufferings" is that we are always and essentially guilty before God. Besides, Kierkegaard's findings "confirm" the old Biblical truth present in both the Old and the New Testament that the way of perfection is the way of difficulty. (Sir 2:1; Ac 14:22; 1 Th 3:3-4) Kierkegaard finds out that there might be no other topic on which the Bible says the same so many times. (Kierkegaard, 1993: 292) Scholastics have expressed this truth by the term "bonum arduum". As this paper shows, Kierkegaard also shared this view. He believed and argued that spiritual growth and bliss are possible only through suffering.

\section{Acknowledgment}

The Research Programme Ethical-religious Grounds and Perspectives of the Society and the Religious Studies in Context of Education and Violence (P6-0269) and the basic research projects Holistic approach to business and human rights: a normative reform of Slovenian and international legal order (J5-1790), Reanimating Cosmic Justice: Poetics of the Feminine (J6-8265) and Interreligious Dialogue - a Basis for Coexisting Diversity in the Light of Migration and the Refugee Crisis (J6-9393) are financed by the Slovenian Research Agency. This article was published with the support of the mentioned programme and projects. I thank the agency for the support.

\section{Bibliographic references}

BINETTI, M. - PAVLIKOVA, M. 2019. Kierkegaard on the reconciliation of conscience. In: XLinguae, vol. 12, n. 3, pp. 192-200. ISSN 1337-8384.

BENJAMIN, A. - CUFF SNOW, S. 2012. Economies of Suffering: Kierkegaard and Levinas. In: Perspectives on Human Suffering, eds. Jeff Malpas and Norelle Lickiss. Dodrecht et al.: Springer, pp. 35-42. ISBN 978-94-007-2794-6.

KHAN, A. 2018. Kierkegaard Americanus: towards establishing a comparative analysis unit. In: XLinguae, vol. 11, n. 3, pp. 2-10. ISSN 1337-8384

KIERKEGAARD, S. 1955. Kierkegaard-Brevier. Wiesbaden: Insel-Verlag. ISBN: n/a.

KIERKEGAARD, S. 1983. Christian Discourses and The Crisis and a Crisis in the Life of an Actress. Princeton: Princeton University Press. ISBN 1-400810-329.

KIERKEGAARD, S. 1990. Eighteen Upbuilding Discourses. Princeton: Princeton University Press. ISBN 0-691-07380-5.

KIERKEGAARD, S. 1991a. Practice in Christianity. Princeton: Princeton University Press. ISBN 0-691-07396-1.

KIERKEGAARD, S. 1991b. Attack Upon “Christendom". Princeton: Princeton University Press. ISBN 0-691-07102-0.

KIERKEGAARD, S. 1993. Upbuilding Discourses in Various Spirits. Princeton: Princeton University Press. ISBN 0-691-03274-2. 
KIERKEGAARD, S. 1998. The Moment and Late Writings. Princeton: Princeton University Press. ISBN 0-691-03226-2.

KONDRLA, P. - DURKOVA, E. 2018. Interpersonal relations in ethics of science and technologies. In: Communications - Scientific Letters of the University of Zilina, vol. 20, n. 1, Part A, pp. 45-50. ISSN 1335-4205.

LEVINAS, E. 1998. Entre nous: On thinking-of-the-other. New York: Columbia University Press. 0-231-07910-9.

MAHRIK, T. - VASBIEVA, D. - KRALIK, R - KONDRLA, P. 2020. Salvation as the teleological vector in Kierkegaard's practice in Christianity, In: European Journal of Science and Theology, vol.16, n. .4, pp.43-52. ISSN 1841-0464.

MARTIN, J. G. - ROJAS, A. M. - KRALIK, R. 2020. The problem of the 'individual' concept in the Kierkegaard's journals. In: European Journal of Science and Theology, vol. 16, n. 2, pp. 39-46. ISSN 1841-0464.

PETERS, T. 2011. Progres and Provolution: Will Transhumanism Leave Sin Behind? In: Transhumanism and Transcendence: Christian Hope in an Age of Technological Enhancement, ed. Ronald Cole-Turnes. Washington, DC: Georgetown University Press, pp. 63-86. 978-58901-780-1.

ROBERTS, R. C. 1995. Kierkegaard, Wittgenstein, and a Method of "Virtue Ethics", In: Kierkegaard in Post/Modernity, eds. Martin J. Matuštík and Merold Westphal. Bloomington and Indianapolis: Indiana University Press, pp. 142-166. ISBN 0-25320967-6.

STRAHOVNIK, V. Spoznavna (ne)pravičnost, krepost spoznavne ponižnosti in monoteizem. [Epistemic (In)justice, the Virtue of Epistemic Humility and Monotheism]. In: Bogoslovni vestnik/Theological Quarterly, vol. 78, no. 2, pp. 299311. ISSN 0006-5722.

TAVILLA, I. - KRALIK, R. - ROUBALOVA, M. 2019. Abraham and the tortoise: Eleatic variations on Fear and Trembling. In: XLinguae, vol. 12, n. 4, pp. 219-228. ISSN 1337-8384.

TAYLOR, C. 2007. A Secular Age. Cambridge, MA and London, England: The Belknap Press of Harvard University Press. ISBN 978-0-674-02676-6.

TIETJEN, M. A. 2013. Kierkegaard, Communication, and Virtue. Authorship as Edification. Bloomington and Indianapolis: Indiana University Press. ISBN 978-0253-00862-6.

VALCO, M. 2016. The Roots and nature of Luther's theological understanding of 'Missio Dei' in the context of his reformation agenda. In: European journal of science and theology, vol. 12, n. 4, pp. 181-188. ISSN 1841-0464.

VALCO, M. 2017. The value of Dietrich Bonhoeffer's theological-ethical reading of Soren Kierkegaard. In: European Journal of Science and Theology, vol. 13, n. 1, pp. 47-58. ISSN 1841-0464.

WALSH, S. 2009. Kierkegaard: Thinking Christianly in an Existential Mode. Oxford and New York: Oxford University Press. ISBN 978-0-19-920835-7.

WESTPHAL, M. 2014. Kierkegaard's Concept of Faith. Grand Rapids and Cambridge: William B. Eerdmans Publishing Company. 978-0-8028-6806-0.

ZALEC, B. 2017a. Preferential and non-preferential love in light of Kierkegaard's thought. European Journal of Science and Theology, vol. 13, n. 2, pp. 179-189. ISSN 1842-8517.

ZALEC, B. 2017b. Human refusal of the basic truth about self as the origin of violence. In: Truth and Compassion: Lessons from the Past and Premonitions of the Future, eds. Robert Petkovsek and Bojan Zalec. Wien \& Zürich: Lit, pp. 29-39. ISBN 978-3-643-90773-8.

ZALEC, B. 2018. Kierkegaard's method: edification and moral grammar of Christian virtues. European Journal of Science and Theology, vol. 14, no. 6, pp. 47-54. ISSN 1842-8517.

XLinguae, Volume 13 Issue 3, June 2020, ISSN 1337-8384, ISSN 2453-711X 
Words:5829

Characters:35 753 (19.86 standard pages)

Research Professor Bojan Žalec, PhD

Faculty of Theology

University of Ljubljana

Poljanska c. 4, 1000 Ljubljana

Slovenia

bojan.zalec@teof.uni-lj.si 